\title{
The 100 Most Cited vs. Most Relevant Articles in the Journal of Neurosurgery: A Bibliometric Analysis
}

Bolin Liu ${ }^{1}$, Shujuan Liu ${ }^{2}$, Anthony Alastra ${ }^{3}$, Deependra Mahato ${ }^{3}$, Emilio C. Tayag ${ }^{4}$, Vladimir A. Cortez ${ }^{5}$ , Javed Siddiqi $3,6,7,8$

1. Neurosurgery, Xi'an International Medical Center, Xi'an, CHN 2. Obstetrics and Gynecology, Xijing Hospital, Xi'an, CHN 3. Neurosurgery, Desert Regional Medical Center, Palm Springs, USA 4. Neurology and Neurosurgery, Desert Regional Medical Center, Palm Springs, USA 5. Neurosurgery, Redlands Community Hospital, Redlands, USA 6. Neurological Surgery, Riverside University Health System Medical Center, Moreno Valley, USA 7. Neurological Surgery, Arrowhead Regional Medical Center, Colton, USA 8. Surgery, California University of Science and Medicine, Colton, USA

Corresponding author: Anthony Alastra, alastra1580@gmail.com

\section{Abstract}

\section{Introduction}

The Journal of Neurosurgery (JNS) published its first volume in 1944 and has evolved into the top cited journal in the field of neurosurgery. The aim of this study was to determine and characterize the 100 most cited (based on the total number of citations) vs. most relevant (based on the number of citations per year) articles originating in JNS.

\section{Methods}

The top 100 most cited articles in JNS were determined by searching the Web of Science database. Citations per year were additionally calculated for the top 1000 articles by total citations to rank the 100 most relevant articles.

\section{Results}

The median number of total citations for the 100 most cited articles in JNS was 505 (range 383-2200), and the median number of citations per year for the 100 most relevant articles was 21.88 (range 17.3182.61). The median year of publication for the 100 most cited and most relevant articles was 1990 and 1999 , respectively $(\mathrm{P}<0.0001)$. Most articles originated in the United States in both categories $(72 \%$ and $71 \%$, respectively). The most common topic of study was cerebrovascular on both lists, followed by trauma on the most cited list vs. tumor on the most relevant list. The most relevant list also contained considerably more articles with a higher level of evidence such as systemic reviews/meta-analyses and prospective studies.

\section{Conclusions}

This study highlights the key contributing factors to the growth and flourishing of JNS. It also reveals several discrepancies between the most cited and most relevant articles, with the latter including more recently published articles, more studies addressing tumor, and more level I/1 (NHMRC/CEBM) evidence. Bibliometric analysis serves as a useful tool for clinicians and researchers to appraise published literature and understand the scientific foundation of modern neurosurgery.

Categories: Medical Education, Neurosurgery, Quality Improvement Keywords: bibliometrics, citation analysis, neurosurgery, relevancy

\section{Introduction}

The Journal of Neurosurgery (JNS), the official journal of the American Association of Neurological Surgeons (AANS) since 1944, has been dedicated to publishing state-of-the-art work relating to neurosurgery, which include but are not limited to clinical studies, laboratory investigations, technical notes, literature and systematic reviews, and expert opinions [1]. Numerous landmark articles that shape the scope and practice of neurosurgeons nowadays are published in JNS. Its leadership in the field of scientific publication has been acknowledged worldwide, currently as the top neurosurgical journal with an impact factor of 4.318 according to the latest Thomson Reuters Journal Citation Reports (JCR) [2].

With over 65 years of growth and maturation, JNS has witnessed the foundation and development of modern 
neurosurgery. Hence it is important not only to evaluate the academic significance of the articles published in JNS, but also seek their unifying elements. The number of citations of individual articles reflects its academic importance and impetus to encourage changes in practice or to lead future studies. Bibliometric analysis is therefore commonly applied to appraise the academic influence of journals and the articles therein [3-6]. Specifically, single journal analysis (of top-cited articles) serves as a useful tool to examine the objective performance and development of the journal [6-8] and thus is of significance to JNS as well. With the ranking of articles according to total citation counts, this would enable us to identify classic and foundational works and appraise their impact in their related fields.

However, an acknowledged limitation of using the total number of citations as a measure of impact is that older publications are favored over newer ones. Additionally, it is hard to determine the impact over time or the persisting significance of older publications by means of total citations. Previous analyses have overcome the bias of total citations by using an alternative measure of impact, i.e. the number of citations per year $[3,9]$. This method may reveal the relevance of individual articles in modern practice by taking into account the effect of time. In light of this, we have performed a secondary citation analysis of articles published in JNS according to the number of citations per year.

The aim of this study was to determine and rank the 100 most cited (based on the total number of citations) and most relevant (based on the number of citations per year) articles originating in JNS respectively. Furthermore, the characteristics of the two rank lists were analyzed and compared regarding publication year, sources, (authorship, institution, country of origin) topic of article, type of article, and level of evidence.

\section{Materials And Methods \\ Search strategy and data collection}

The Web of Science database was searched on December 23, 2018 under "publication name" = Journal of Neurosurgery, with the inclusion of all article types and period 1944 to 2018. The results were ordered by "times cited" to yield a rank list of articles according to their numbers of total citations. The list of 100 most cited articles published in JNS was obtained with the ranking of total citations.

Since the database has not yet developed the function to sort results by "times cited per year", we adopted the strategy of Bohl and Ponce's study [3] by assuming that the top 100 articles ranked by number of citations per year would be captured within the list of the 1000 articles ranked by total number of citations. We then calculated the number of citations per year for each article using a similar method described previously [3]. Briefly, the number of months since publication was calculated from the publication month and year to the current month and year (December 2018). Articles without a month of publication were assumed to have been published in June. The number of years since publication was then calculated by dividing the months by 12 . The number of citations per year was gained by dividing the total number of citations by the number of years since publication. The list of 100 most relevant articles published in JNS was thus generated by ranking with the number of citations per year.

The following information was further collected for each article from the rank lists: year of publication, sources (authorship, institution, country of origin) based on the corresponding author, of article (cerebrovascular, trauma, tumor, functional neurosurgery), type of article including clinical studies (retrospective, prospective, randomized controlled trials, case series, case reports), laboratory studies, reviews/meta-analysis, and guidelines/consensus statements. The level of evidence was determined according to the Australian National Health and Medical Research Council (NHMRC) and Oxford Centre for Evidence-based Medicine (CEBM) evidence hierarchy [10-11]. Articles of animal studies, laboratory studies, technical notes, and case reports were not included in such evidence hierarchy and thus were classified as level 0 .

\section{Statistical analysis}

Comparisons between continuous data were done using ANOVA or Mann-Whitney U test according to the testing condition. Statistical significance was defined as $\mathrm{p}<0.05$. All of the tests were two-sided. Statistical analysis was performed using SPSS software (version 16.0, SPSS, Inc).

\section{Results}

The 100 most cited articles published in JNS ranked by total number of citations are shown in Table 1 . The median total number of citations was 505 (range 383-2200). The 100 most relevant articles published in JNS ranked by number of citations per year are shown in Table 2 . The median number of citations per year was 21.88 (range 17.31-82.61). The most cited article was the Hunt-Hess grading scale for patients with subarachnoid hemorrhage (SAH) published in 1968 [12], while the most relevant article was the extent of resection and prognostic factors for survival in patients with glioblastoma multiforme (GBM) published by 


\section{Cureus}

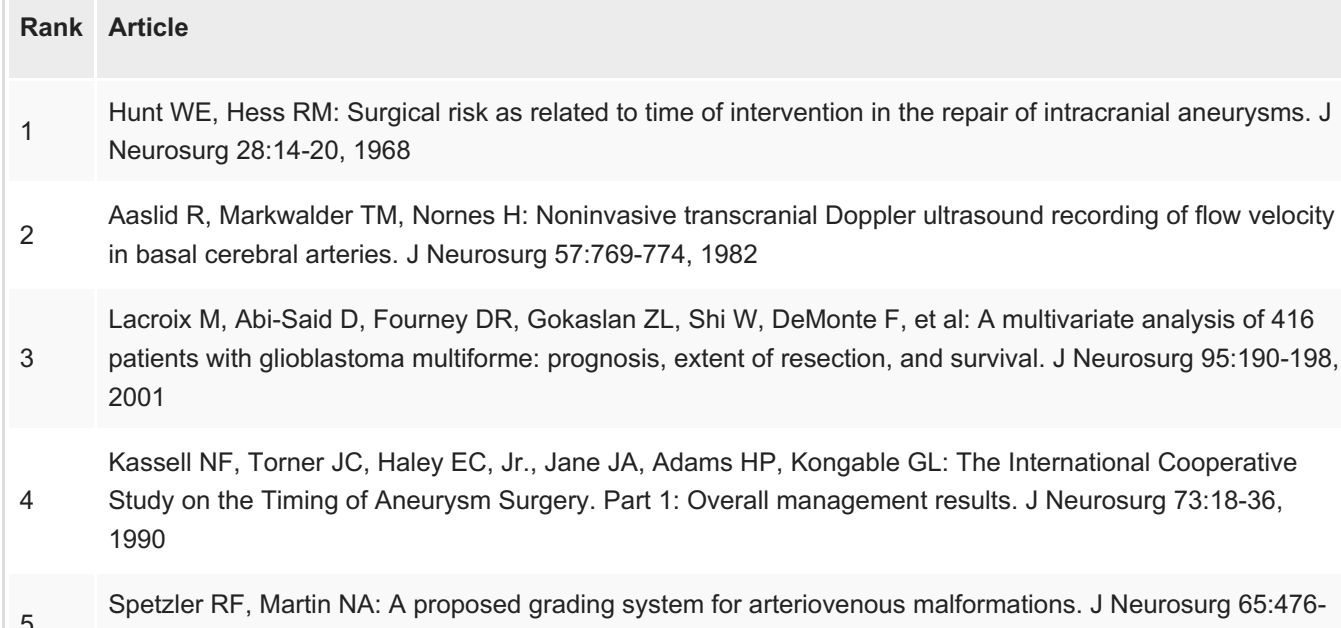

Hunt WE, Hess RM: Surgical risk as related to time of intervention in the repair of intracranial aneurysms. J Neurosurg 28:14-20, 1968

2

Aaslid R, Markwalder TM, Nornes H: Noninvasive transcranial Doppler ultrasound recording of flow velocity in basal cerebral arteries. J Neurosurg 57:769-774, 1982

Lacroix M, Abi-Said D, Fourney DR, Gokaslan ZL, Shi W, DeMonte F, et al: A multivariate analysis of 416

3 patients with glioblastoma multiforme: prognosis, extent of resection, and survival. J Neurosurg 95:190-198, 2001

Kassell NF, Torner JC, Haley EC, Jr., Jane JA, Adams HP, Kongable GL: The International Cooperative

4 Study on the Timing of Aneurysm Surgery. Part 1: Overall management results. J Neurosurg 73:18-36, 1990

Spetzler RF, Martin NA: A proposed grading system for arteriovenous malformations. J Neurosurg 65:476483, 1986

Walker MD, Alexander E, Jr., Hunt WE, MacCarty CS, Mahaley MS, Jr., Mealey J, Jr., et al: Evaluation of $\mathrm{BCNU}$ and/or radiotherapy in the treatment of anaplastic gliomas. A cooperative clinical trial. J Neurosurg 49:333-343, 1978

Ojemann G, Ojemann J, Lettich E, Berger M: Cortical language localization in left, dominant hemisphere. An electrical stimulation mapping investigation in 117 patients. J Neurosurg 71:316-326, 1989

Guglielmi G, Vinuela F, Dion J, Duckwiler G: Electrothrombosis of saccular aneurysms via endovascular approach. Part 2: Preliminary clinical experience. J Neurosurg 75:8-14, 1991

Marmarou A, Foda MA, van den Brink W, Campbell J, Kita H, Demetriadou K: A new model of diffuse brain injury in rats. Part I: Pathophysiology and biomechanics. J Neurosurg 80:291-300, 1994

Laitinen LV, Bergenheim AT, Hariz MI: Leksell's posteroventral pallidotomy in the treatment of Parkinson's disease. J Neurosurg 76:53-61, 1992

Jones TH, Morawetz RB, Crowell RM, Marcoux FW, FitzGibbon SJ, DeGirolami U, et al: Thresholds of focal cerebral ischemia in awake monkeys. J Neurosurg 54:773-782, 1981

Katayama Y, Becker DP, Tamura T, Hovda DA: Massive increases in extracellular potassium and the indiscriminate release of glutamate following concussive brain injury. J Neurosurg 73:889-900, 1990

Siesjo BK: Pathophysiology and treatment of focal cerebral ischemia. Part I: Pathophysiology. J Neurosurg $77: 169-184,1992$

Dixon CE, Lyeth BG, Povlishock JT, Findling RL, Hamm RJ, Marmarou A, et al: A fluid percussion model of experimental brain injury in the rat. J Neurosurg 67:110-119, 1987

Benabid AL, Pollak P, Gao D, Hoffmann D, Limousin P, Gay E, et al: Chronic electrical stimulation of the

18 ventralis intermedius nucleus of the thalamus as a treatment of movement disorders. J Neurosurg 84:203214, 1996

19 Locksley HB: Natural history of subarachnoid hemorrhage, intracranial aneurysms and arteriovenous malformations. Based on 6368 cases in the cooperative study. J Neurosurg 25:219-239, 1966

Ondra SL, Troupp H, George ED, Schwab K: The natural history of symptomatic arteriovenous malformations of the brain: a 24-year follow-up assessment. J Neurosurg 73:387-391, 1990

Vinuela F, Duckwiler G, Mawad M: Guglielmi detachable coil embolization of acute intracranial aneurysm: 

1974

Guglielmi G, Vinuela F, Sepetka I, Macellari V: Electrothrombosis of saccular aneurysms via endovascular approach. Part 1: Electrochemical basis, technique, and experimental results. J Neurosurg 75:1-7, 1991

Mirimanoff RO, Dosoretz DE, Linggood RM, Ojemann RG, Martuza RL: Meningioma: analysis of recurrence and progression following neurosurgical resection. J Neurosurg 62:18-24, 1985

Kassell NF, Torner JC, Jane JA, Haley EC, Jr., Adams HP: The International Cooperative Study on the Timing of Aneurysm Surgery. Part 2: Surgical results. J Neurosurg 73:37-47, 1990

Report of World Federation of Neurological Surgeons Committee on a Universal Subarachnoid Hemorrhage Grading Scale. J Neurosurg 68:985-986, 1988

Muizelaar JP, Marmarou A, Ward JD, Kontos HA, Choi SC, Becker DP, et al: Adverse effects of prolonged

Becker DP, Miller JD, Ward JD, Greenberg RP, Young HF, Sakalas R: The outcome from severe head injury with early diagnosis and intensive management. J Neurosurg 47:491-502, 1977

Barrow DL, Spector RH, Braun IF, Landman JA, Tindall SC, Tindall GT: Classification and treatment of spontaneous carotid-cavernous sinus fistulas. J Neurosurg 62:248-256, 1985

Siesjo BK: Pathophysiology and treatment of focal cerebral ischemia. Part II: Mechanisms of damage and treatment. J Neurosurg 77:337-354, 1992

Rosner MJ, Rosner SD, Johnson AH: Cerebral perfusion pressure: management protocol and clinical results. J Neurosurg 83:949-962, 1995

Rivlin AS, Tator $\mathrm{CH}$ : Objective clinical assessment of motor function after experimental spinal cord injury in

Obrist WD, Langfitt TW, Jaggi JL, Cruz J, Gennarelli TA: Cerebral blood flow and metabolism in comatose patients with acute head injury. Relationship to intracranial hypertension. J Neurosurg 61:241-253, 1984

Yasargil MG, Curcic M, Kis M, Siegenthaler G, Teddy PJ, Roth P: Total removal of craniopharyngiomas.

Kelly PJ, Daumas-Duport C, Kispert DB, Kall BA, Scheithauer BW, Illig JJ: Imaging-based stereotaxic seria biopsies in untreated intracranial glial neoplasms. J Neurosurg 66:865-874, 1987

Jannetta $\mathrm{PJ}$ : Arterial compression of the trigeminal nerve at the pons in patients with trigeminal neuralgia. $\mathrm{J}$ Neurosurg 26:Suppl:159-162, 1967

Borden JA, Wu JK, Shucart WA: A proposed classification for spinal and cranial dural arteriovenous fistulous malformations and implications for treatment. J Neurosurg 82:166-179, 1995

Miller JD, Becker DP, Ward JD, Sullivan HG, Adams WE, Rosner MJ: Significance of intracranial hypertension in severe head injury. J Neurosurg 47:503-516, 1977

Perret G, Nishioka H: Report on the cooperative study of intracranial aneurysms and subarachnoid

43 hemorrhage. Section VI. Arteriovenous malformations. An analysis of 545 cases of cranio-cerebral arteriovenous malformations and fistulae reported to the cooperative study. J Neurosurg 25:467-490, 1966 
45 Graf CJ, Perret GE, Torner JC: Bleeding from cerebral arteriovenous malformations as part of their natural history. J Neurosurg 58:331-337, 1983

Stummer W, Novotny A, Stepp H, Goetz C, Bise K, Reulen HJ: Fluorescence-guided resection of

46 glioblastoma multiforme by using 5-aminolevulinic acid-induced porphyrins: a prospective study in 52 consecutive patients. J Neurosurg 93:1003-1013, 2000

Oldfield EH, Muraszko K, Shawker TH, Patronas NJ: Pathophysiology of syringomyelia associated with

47 Chiari I malformation of the cerebellar tonsils. Implications for diagnosis and treatment. J Neurosurg 80:315, 1994

Lunsford LD, Kondziolka D, Flickinger JC, Bissonette DJ, Jungreis CA, Maitz AH, et al: Stereotactic radiosurgery for arteriovenous malformations of the brain. J Neurosurg 75:512-524, 1991

Zabramski JM, Wascher TM, Spetzler RF, Johnson B, Golfinos J, Drayer BP, et al: The natural history of familial cavernous malformations: results of an ongoing study. J Neurosurg 80:422-432, 1994

Sanai N, Polley M-Y, McDermott MW, Parsa AT, Berger MS: An extent of resection threshold for newly diagnosed glioblastomas. J Neurosurg 115:3-8, 2011

51 Bouma GJ, Muizelaar JP, Choi SC, Newlon PG, Young HF: Cerebral circulation and metabolism after severe traumatic brain injury: the elusive role of ischemia. J Neurosurg 75:685-693, 1991

Awad IA, Little JR, Akarawi WP, Ahl J: Intracranial dural arteriovenous malformations: factors predisposing to an aggressive neurological course. J Neurosurg 72:839-850, 1990

53 Backlund EO, Granberg PO, Hamberger B, Knutsson E, Martensson A, Sedvall G, et al: Transplantation of adrenal medullary tissue to striatum in parkinsonism. First clinical trials. J Neurosurg 62:169-173, 1985

Rorke LB, Packer RJ, Biegel JA: Central nervous system atypical teratoid/rhabdoid tumors of infancy and childhood: definition of an entity. J Neurosurg 85:56-65, 1996

Bracken MB, Shepard MJ, Collins WF, Jr., Holford TR, Baskin DS, Eisenberg HM, et al: Methylprednisolone or naloxone treatment after acute spinal cord injury: 1-year follow-up data. Results of the second National Acute Spinal Cord Injury Study. J Neurosurg 76:23-31, 1992

Jho HD, Carrau RL: Endoscopic endonasal transsphenoidal surgery: experience with 50 patients. J Neurosurg 87:44-51, 1997

Aaslid R, Huber P, Nornes $\mathrm{H}$ : Evaluation of cerebrovascular spasm with transcranial Doppler ultrasound. J Neurosurg 60:37-41, 1984

Woolsey CN, Erickson TC, Gilson WE: Localization in somatic sensory and motor areas of human cerebral

Brown RD, Jr., Wiebers DO, Forbes G, O'Fallon WM, Piepgras DG, Marsh WR, et al: The natural history of unruptured intracranial arteriovenous malformations. J Neurosurg 68:352-357, 1988

Paddick I: A simple scoring ratio to index the conformity of radiosurgical treatment plans. Technical note. $J$

64 McCormick WF: The pathology of vascular ("arteriovenous") malformations. J Neurosurg 24:807-816, 1966 

68 Jannetta PJ, Abbasy M, Maroon JC, Ramos FM, Albin MS: Etiology and definitive microsurgical treatment 454

Weir B, Grace M, Hansen J, Rothberg C: Time course of vasospasm in man. J Neurosurg 48:173-178, 1978

Steiner L, Lindquist C, Adler JR, Torner JC, Alves W, Steiner M: Clinical outcome of radiosurgery for

Marmarou A, Shulman K, LaMorgese J: Compartmental analysis of compliance and outflow resistance of the cerebrospinal fluid system. J Neurosurg 43:523-534, 1975

Goldsmith BJ, Wara WM, Wilson CB, Larson DA: Postoperative irradiation for subtotally resected 1994

McCormick PC, Torres R, Post KD, Stein BM: Intramedullary ependymoma of the spinal cord. J Neurosurg

Juvela S, Porras M, Poussa K: Natural history of unruptured intracranial aneurysms: probability of and risk

Kondziolka D, Lunsford LD, Kestle JR: The natural history of cerebral cavernous malformations. J Neurosurg 83:820-824, 1995

Del Curling O, Jr., Kelly DL, Jr., Elster AD, Craven TE: An analysis of the natural history of cavernous angiomas. J Neurosurg 75:702-708, 1991

Laws ER, Parney IF, Huang W, Anderson F, Morris AM, Asher A, et al: Survival following surgery and prognostic factors for recently diagnosed malignant glioma: data from the Glioma Outcomes Project. J Neurosurg 99:467-473, 2003

Evans AE, Jenkin RD, Sposto R, Ortega JA, Wilson CB, Wara W, et al: The treatment of medulloblastoma.

Simpkins JW, Rajakumar G, Zhang YQ, Simpkins CE, Greenwald D, Yu CJ, et al: Estrogens may reduce

82 mortality and ischemic damage caused by middle cerebral artery occlusion in the female rat. J Neurosurg 87:724-730, 1997

Rigamonti D, Drayer BP, Johnson PC, Hadley MN, Zabramski J, Spetzler RF: The MRI appearance of cavernous malformations (angiomas). J Neurosurg 67:518-524, 1987

84 Siesjo BK: Cerebral circulation and metabolism. J Neurosurg 60:883-908, 1984

Laws ER, Jr., Taylor WF, Clifton MB, Okazaki H: Neurosurgical management of low-grade astrocytoma of the cerebral hemispheres. J Neurosurg 61:665-673, 1984

Locksley HB: Natural history of subarachnoid hemorrhage, intracranial aneurysms and arteriovenous malformations. J Neurosurg 25:321-368, 1966

Nashold BS, Jr., Wilson WP, Slaughter DG: Sensations evoked by stimulation in the midbrain of man. J Neurosurg 30:14-24, 1969 


\section{Cureus}

1989

Narayan RK, Greenberg RP, Miller JD, Enas GG, Choi SC, Kishore PR, et al: Improved confidence of

90 outcome prediction in severe head injury. A comparative analysis of the clinical examination, multimodality

evoked potentials, CT scanning, and intracranial pressure. J Neurosurg 54:751-762, 1981

Eisenberg HM, Gary HE, Jr., Aldrich EF, Saydjari C, Turner B, Foulkes MA, et al: Initial CT findings in 753

91 patients with severe head injury. A report from the NIH Traumatic Coma Data Bank. J Neurosurg 73:688698,1990

Bouma GJ, Muizelaar JP, Stringer WA, Choi SC, Fatouros P, Young HF: Ultra-early evaluation of regional cerebral blood flow in severely head-injured patients using xenon-enhanced computerized tomography. J Neurosurg 77:360-368, 1992

Luerssen TG, Klauber MR, Marshall LF: Outcome from head injury related to patient's age. A longitudinal prospective study of adult and pediatric head injury. J Neurosurg 68:409-416, 1988

Gennarelli TA, Spielman GM, Langfitt TW, Gildenberg PL, Harrington T, Jane JA, et al: Influence of the type of intracranial lesion on outcome from severe head injury. J Neurosurg 56:26-32, 1982

Byrne JV, Sohn MJ, Molyneux AJ, Chir B: Five-year experience in using coil embolization for ruptured

Marshall LF, Smith RW, Shapiro HM: The outcome with aggressive treatment in severe head injuries. Part I: the significance of intracranial pressure monitoring. J Neurosurg 50:20-25, 1979

Madawi AA, Casey AT, Solanki GA, Tuite G, Veres R, Crockard HA: Radiological and anatomical evaluation of the atlantoaxial transarticular screw fixation technique. J Neurosurg 86:961-968, 1997

Marmarou A, Shulman K, Rosende RM: A nonlinear analysis of the cerebrospinal fluid system and intracranial pressure dynamics. J Neurosurg 48:332-344, 1978

\section{TABLE 1: The 100 most cited articles from the Journal of Neurosurgery}

\section{Rank Article}

Lacroix M, Abi-Said D, Fourney DR, Gokaslan ZL, Shi W, DeMonte F, et al: A multivariate analysis of 416

1 patients with glioblastoma multiforme: prognosis, extent of resection, and survival. J Neurosurg 95:190-198, 2001

Sanai N, Polley M-Y, McDermott MW, Parsa AT, Berger MS: An extent of resection threshold for newly diagnosed glioblastomas. J Neurosurg 115:3-8, 2011 Aaslid R, Markwalder TM, Nornes H: Noninvasive transcranial Doppler ultrasound recording of flow velocity in basal cerebral arteries. J Neurosurg 57:769-774, 1982

Kassell NF, Torner JC, Haley EC, Jr., Jane JA, Adams HP, Kongable GL: The International Cooperative

$4 \quad$ Study on the Timing of Aneurysm Surgery. Part 1: Overall management results. J Neurosurg 73:18-36, 1990

5 Hunt WE, Hess RM: Surgical risk as related to time of intervention in the repair of intracranial aneurysms. J Neurosurg 28:14-20, 1968

Spetzler RF, Martin NA: A proposed grading system for arteriovenous malformations. J Neurosurg 65:476483, 1986

Juvela S, Porras M, Poussa K: Natural history of unruptured intracranial aneurysms: probability of and risk

7 factors for aneurysm rupture (Reprinted from J Neurosurg, vol 93, pg 379-387, 2000). J Neurosurg 108:1052-1060, 2008 
Marmarou A, Foda MA, van den Brink W, Campbell J, Kita H, Demetriadou K: A new model of diffuse brain injury in rats. Part I: Pathophysiology and biomechanics. J Neurosurg 80:291-300, 1994

Tator $\mathrm{CH}$, Fehlings MG: Review of the secondary injury theory of acute spinal cord trauma with emphasis on vascular mechanisms. J Neurosurg 75:15-26, 1991

McGirt MJ, Chaichana KL, Gathinji M, Attenello FJ, Than K, Olivi A, et al: Independent association of extent

11 of resection with survival in patients with malignant brain astrocytoma. Journal of Neurosurgery 110:156162,2009

Kassam AB, Preveoello DM, Carrau RL, Snyderman CH, Thomas A, Gardner P, et al: Endoscopic

12 endonasal skull base surgery: analysis of complications in the authors' initial 800 patients. Journal of Neurosurgery 114:1544-1568, 2011

McDougall CG, Spetzler RF, Zabramski JM, Partovi S, Hills NK, Nakaji P, et al: The Barrow Ruptured Aneurysm Trial. Journal of Neurosurgery 116:135-144, 2012

Zhang Y, Chopp M, Meng Y, Katakowski M, Xin H, Mahmood A, et al: Effect of exosomes derived from

14 multipluripotent mesenchyrnal stromal cells on functional recovery and neurovascular plasticity in rats after traumatic brain injury. Journal of Neurosurgery 122:856-867, 2015

Benabid AL, Pollak P, Gao D, Hoffmann D, Limousin P, Gay E, et al: Chronic electrical stimulation of the

15 ventralis intermedius nucleus of the thalamus as a treatment of movement disorders. J Neurosurg 84:203214, 1996

Vinuela F, Duckwiler G, Mawad M: Guglielmi detachable coil embolization of acute intracranial aneurysm: perioperative anatomical and clinical outcome in 403 patients. J Neurosurg 86:475-482, 1997

Ojemann G, Ojemann J, Lettich E, Berger M: Cortical language localization in left, dominant hemisphere

17 An electrical stimulation mapping investigation in 117 patients. J Neurosurg 71:316-326, 1989

Guglielmi G, Vinuela F, Dion J, Duckwiler G: Electrothrombosis of saccular aneurysms via endovascular approach. Part 2: Preliminary clinical experience. J Neurosurg 75:8-14, 1991

Levy RM, Bredesen DE, Rosenblum ML: Neurological manifestations of the acquired immunodeficiency syndrome (AIDS): experience at UCSF and review of the literature. J Neurosurg 62:475-495, 1985

Walker MD, Alexander E, Jr., Hunt WE, MacCarty CS, Mahaley MS, Jr., Mealey J, Jr., et al: Evaluation of

$20 \mathrm{BCNU}$ and/or radiotherapy in the treatment of anaplastic gliomas. A cooperative clinical trial. J Neurosurg 49:333-343, 1978

Laitinen LV, Bergenheim AT, Hariz MI: Leksell's posteroventral pallidotomy in the treatment of Parkinson's disease. J Neurosurg 76:53-61, 1992

Gross BA, Du R: Natural history of cerebral arteriovenous malformations: a meta-analysis. Journal of Neurosurgery 118:437-443, 2013

Siesjo BK: Pathophysiology and treatment of focal cerebral ischemia. Part I: Pathophysiology. J Neurosurg 77:169-184, 1992

Fourney DR, Schomer DF, Nader R, Chlan-Fourney J, Suki D, Ahrar K, et al: Percutaneous vertebroplasty and kyphoplasty for painful vertebral body fractures in cancer patients. J Neurosurg 98:21-30, 2003

Aarabi B, Hesdorffer DC, Ahn ES, Aresco C, Scalea TM, Eisenberg HM: Outcome following decompressive craniectomy for malignant swelling due to severe head injury. Journal of neurosurgery 104:469-479, 2006

Stummer W, Novotny A, Stepp H, Goetz C, Bise K, Reulen HJ: Fluorescence-guided resection of

26 glioblastoma multiforme by using 5-aminolevulinic acid-induced porphyrins: a prospective study in 52 consecutive patients. J Neurosurg 93:1003-1013, 2000 
29 Rosner MJ, Rosner SD, Johnson AH: Cerebral perfusion pressure: management protocol and clinical results. J Neurosurg 83:949-962, 1995

Farquharson S, Tournier JD, Calamante F, Fabinyi G, Schneider-Kolsky M, Jackson GD, et al: White matter fiber tractography: why we need to move beyond DTI. Journal of Neurosurgery 118:1367-1377, 2013

Guglielmi G, Vinuela F, Sepetka I, Macellari V: Electrothrombosis of saccular aneurysms via endovascular approach. Part 1: Electrochemical basis, technique, and experimental results. J Neurosurg 75:1-7, 1991

Ondra SL, Troupp H, George ED, Schwab K: The natural history of symptomatic arteriovenous malformations of the brain: a 24-year follow-up assessment. J Neurosurg 73:387-391, 1990

Inglese M, Makani S, Johnson G, Cohen BA, Silver JA, Gonen O, et al: Diffuse axonal injury in mild traumatic brain injury: a diffusion tensor imaging study. Journal of neurosurgery 103:298-303, 2005

Duffau H, Gatignol P, Mandonnet E, Capelle L, Taillandier L: Intraoperative subcortical stimulation mapping

Paddick I: A simple scoring ratio to index the conformity of radiosurgical treatment plans. Technical note. J Neurosurg 93 Suppl 3:219-222, 2000

Dixon CE, Lyeth BG, Povlishock JT, Findling RL, Hamm RJ, Marmarou A, et al: A fluid percussion model of experimental brain injury in the rat. J Neurosurg 67:110-119, 1987

Lozano AM, Giacobbe P, Hamani C, Rizvi SJ, Kennedy SH, Kolivakis TT, et al: A multicenter pilot study of Neurosurgery 116:315-322, 2012

Muizelaar JP, Marmarou A, Ward JD, Kontos HA, Choi SC, Becker DP, et al: Adverse effects of prolonged

38 hyperventilation in patients with severe head injury: a randomized clinical trial. J Neurosurg 75:731-739, 1991

Kassell NF, Torner JC, Jane JA, Haley EC, Jr., Adams HP: The International Cooperative Study on the Timing of Aneurysm Surgery. Part 2: Surgical results. J Neurosurg 73:37-47, 1990

Siesjo BK: Pathophysiology and treatment of focal cerebral ischemia. Part II: Mechanisms of damage and treatment. J Neurosurg 77:337-354, 1992

Chang EF, Potts MB, Keles GE, Lamborn KR, Chang SM, Barbaro NM, et al: Seizure characteristics and 2008

Fahlbusch R, Honegger J, Paulus W, Huk W, Buchfelder M: Surgical treatment of craniopharyngiomas: experience with 168 patients. J Neurosurg 90:237-250, 1999

Borden JA, Wu JK, Shucart WA: A proposed classification for spinal and cranial dural arteriovenous fistulous malformations and implications for treatment. J Neurosurg 82:166-179, 1995

Raabe A, Nakaji P, Beck J, Kim LJ, Hsu FPK, Kamerman JD, et al: Prospective evaluation of surgical

44 microscope-integrated intraoperative near-infrared indocyanine green videoangiography during aneurysm surgery. Journal of neurosurgery 103:982-989, 2005

Bailes JE, Petraglia AL, Omalu BI, Nauman E, Talavage T: Role of subconcussion in repetitive mild

Cameron T: Safety and efficacy of spinal cord stimulation for the treatment of chronic pain: a 20-year literature review. Journal of neurosurgery 100:254-267, 2004

Slevin JT, Gerhardt GA, Smith CD, Gash DM, Kryscio R, Young B: Improvement of bilateral motor functions

Knisely JPS, Yu JB, Flanigan J, Sznol M, Kluger HM, Chiang VLS: Radiosurgery for melanoma brain

49 metastases in the ipilimumab era and the possibility of longer survival. Journal of Neurosurgery 117:227233, 2012 
Report of World Federation of Neurological Surgeons Committee on a Universal Subarachnoid Hemorrhage Grading Scale. J Neurosurg 68:985-986, 1988

Rorke LB, Packer RJ, Biegel JA: Central nervous system atypical teratoid/rhabdoid tumors of infancy and childhood: definition of an entity. J Neurosurg 85:56-65, 1996

McLaughlin MR, Jannetta PJ, Clyde BL, Subach BR, Comey CH, Resnick DK: Microvascular decompression of cranial nerves: lessons learned after 4400 operations. J Neurosurg 90:1-8, 1999

Zrinzo L, Foltynie T, Limousin P, Hariz MI: Reducing hemorrhagic complications in functional neurosurgery: a large case series and systematic literature review. Journal of Neurosurgery 116:84-94, 2012

Oldfield EH, Muraszko K, Shawker TH, Patronas NJ: Pathophysiology of syringomyelia associated with

56 Chiari I malformation of the cerebellar tonsils. Implications for diagnosis and treatment. J Neurosurg 80:315, 1994

Bloch O, Han SJ, Cha S, Sun MZ, Aghi MK, McDermott MW, et al: Impact of extent of resection for recurrent glioblastoma on overall survival. Journal of Neurosurgery 117:1032-1038, 2012

Matsutani M, Sano K, Takakura K, Fujimaki T, Nakamura O, Funata N, et al: Primary intracranial germ cell tumors: a clinical analysis of 153 histologically verified cases. J Neurosurg 86:446-455, 1997

Zabramski JM, Wascher TM, Spetzler RF, Johnson B, Golfinos J, Drayer BP, et al: The natural history of familial cavernous malformations: results of an ongoing study. J Neurosurg 80:422-432, 1994

Mirimanoff RO, Dosoretz DE, Linggood RM, Ojemann RG, Martuza RL: Meningioma: analysis of recurrence and progression following neurosurgical resection. J Neurosurg 62:18-24, 1985

Yasargil MG, Curcic M, Kis M, Siegenthaler G, Teddy PJ, Roth P: Total removal of craniopharyngiomas.

Lovell MR, Collins MW, Iverson GL, Field M, Maroon JC, Cantu R, et al: Recovery from mild concussion in high school athletes. Journal of neurosurgery 98:296-301, 2003

Tabaee A, Anand VK, Barron Y, Hiltzik DH, Brown SM, Kacker A, et al: Endoscopic pituitary surgery: a systematic review and meta-analysis. Journal of Neurosurgery 111:545-554, 2009

Laufer I, Anand VK, Schwartz TH: Endoscopic, endonasal extended transsphenoidal, transplanum

Siddiqui AH, Abla AA, Kan P, Dumont TM, Jahshan S, Britz GW, et al: Panacea or problem: flow diverters

Hukkelhoven CWPM, Steyerberg EW, Rampen AJJ, Farace E, Habbema JDF, Marshall LF, et al: Patient

Yordanova YN, Moritz-Gasser S, Duffau H: Awake surgery for WHO Grade II gliomas within "noneloquent" areas in the left dominant hemisphere: toward a "supratotal" resection. Journal of Neurosurgery 115:232239, 2011

Huang F-P, Xi G, Keep RF, Hua Y, Nemoianu A, Hoff JT: Brain edema after experimental intracerebral hemorrhage: role of hemoglobin degradation products. Journal of neurosurgery 96:287-293, 2002

Byrne JV, Sohn MJ, Molyneux AJ, Chir B: Five-year experience in using coil embolization for ruptured intracranial aneurysms: outcomes and incidence of late rebleeding. J Neurosurg 90:656-663, 1999 
following minor head injury: a three-center study. J Neurosurg 66:234-243, 1987

Simpkins JW, Rajakumar G, Zhang YQ, Simpkins CE, Greenwald D, Yu CJ, et al: Estrogens may reduce

73 mortality and ischemic damage caused by middle cerebral artery occlusion in the female rat. J Neurosurg 87:724-730, 1997

Duffau H, Capelle L, Denvil D, Sichez N, Gatignol P, Taillandier L, et al: Usefulness of intraoperative

Claus EB, Bondy ML, Schildkraut JM, Wiemels JL, Wrensch M, Black PM: Epidemiology of intracranial meningioma. Neurosurgery 57:1088-1095; discussion 1088-1095, 2005

Higashida T, Kreipke CW, Rafols JA, Peng C, Schafer S, Schafer P, et al: The role of hypoxia-inducible 76 factor-la, aquaporin-4, and matrix metalloproteinase-9 in blood-brain barrier disruption and brain edema after traumatic brain injury. Journal of Neurosurgery 114:92-101, 2011

Cappabianca P, Cavallo LM, Colao A, de Divitiis E: Surgical complications associated with the endoscopic endonasal transsphenoidal approach for pituitary adenomas. Journal of neurosurgery 97:293-298, 2002

Saatci I, Geyik S, Yavuz K, Cekirge HS: Endovascular treatment of brain arteriovenous malformations with prolonged intranidal Onyx injection technique: long-term results in 350 consecutive patients with completed endovascular treatment course. Journal of Neurosurgery 115:78-88, 2011

Barrow DL, Spector RH, Braun IF, Landman JA, Tindall SC, Tindall GT: Classification and treatment of spontaneous carotid-cavernous sinus fistulas. J Neurosurg 62:248-256, 1985

Bracken MB, Shepard MJ, Collins WF, Jr., Holford TR, Baskin DS, Eisenberg HM, et al: Methylprednisolone Acute Spinal Cord Injury Study. J Neurosurg 76:23-31, 1992

Kassam AB, Gardner PA, Snyderman CH, Carrau RL, Mintz AH, Prevedello DM: Expanded endonasal approach, a fully endoscopic transnasal approach for the resection of midline suprasellar 2008

Englot DJ, Chang EF, Auguste KI: Vagus nerve stimulation for epilepsy: a meta-analysis of efficacy and predictors of response. Journal of Neurosurgery 115:1248-1255, 2011

Starr PA, Christine CW, Theodosopoulos PV, Lindsey N, Byrd D, Mosley A, et al: Implantation of deep brain stimulators into the subthalamic nucleus: technical approach and magnetic resonance imagingverified lead locations. Journal of neurosurgery 97:370-387, 2002

Bouma GJ, Muizelaar JP, Choi SC, Newlon PG, Young HF: Cerebral circulation and metabolism after severe traumatic brain injury: the elusive role of ischemia. J Neurosurg 75:685-693, 1991

Guzman R, Lee M, Achrol A, Bell-Stephens T, Kelly M, Do HM, et al: Clinical outcome after 450

88 revascularization procedures for moyamoya disease. Journal of Neurosurgery 111:927-935, 2009

Lunsford LD, Niranjan A, Flickinger JC, Maitz A, Kondziolka D: Radiosurgery of vestibular schwannomas: summary of experience in 829 cases. Journal of neurosurgery 102:195-199, 2005

Davis FG, Freels S, Grutsch J, Barlas S, Brem S: Survival rates in patients with primary malignant brain

90 tumors stratified by patient age and tumor histological type: an analysis based on Surveillance,

Epidemiology, and End Results (SEER) data, 1973-1991. Journal of neurosurgery 88:1-10, 1998

Kondziolka D, Lunsford LD, Kestle JR: The natural history of cerebral cavernous malformations. J Neurosurg 83:820-824, 1995

Kelly PJ, Daumas-Duport C, Kispert DB, Kall BA, Scheithauer BW, Illig JJ: Imaging-based stereotaxic serial biopsies in untreated intracranial glial neoplasms. J Neurosurg 66:865-874, 1987 


\section{Cureus}

94

96

97

98

100

Guglielmi G, Vinuela F, Duckwiler G, Dion J, Lylyk P, Berenstein A, et al: Endovascular treatment of

posterior circulation aneurysms by electrothrombosis using electrically detachable coils. J Neurosurg

Goldsmith BJ, Wara WM, Wilson CB, Larson DA: Postoperative irradiation for subtotally resected

meningiomas. A retrospective analysis of 140 patients treated from 1967 to 1990. J Neurosurg 80:195-201, 435 1994

Mocco J, Snyder KV, Albuquerque FC, Bendok BR, Boulos AS, Carpenter JS, et al: Treatment of 2009

Keles GE, Lamborn KR, Berger MS: Low-grade hemispheric gliomas in adults: a critical review of extent of resection as a factor influencing outcome. Journal of neurosurgery 95:735-745, 2001

Awad IA, Little JR, Akarawi WP, Ahl J: Intracranial dural arteriovenous malformations: factors predisposing to an aggressive neurological course. J Neurosurg 72:839-850, 1990

Bergsneider M, Hovda DA, Shalmon E, Kelly DF, Vespa PM, Martin NA, et al: Cerebral hyperglycolysis following severe traumatic brain injury in humans: a positron emission tomography study. Journal of neurosurgery 86:241-251, 1997

Obrist WD, Langfitt TW, Jaggi JL, Cruz J, Gennarelli TA: Cerebral blood flow and metabolism in comatose patients with acute head injury. Relationship to intracranial hypertension. J Neurosurg 61:241-253, 1984

TABLE 2: The 100 most relevant articles from the Journal of Neurosurgery

Characteristics of the most cited rank list are detailed as follows:

\section{Temporal trends}

Figure 1 shows a sharp increase in the number of most cited articles in the late 1970s, with a decrease in the most recent decade. Seventy-five percent of all most cited articles were published between 1979 and 1999, with the 1990s as the apex $(n=44)$. There was a positive correlation between the total number of citations and the number of citations per year (Pearson coefficient $=0.694, \mathrm{P}<0.0001$ ) (Figure 2 ), whereas a negative correlation was found between the number of citations per year and the number of years since publication (Pearson coefficient $=-0.447, \mathrm{P}<0.0001)$ (Figure 3).

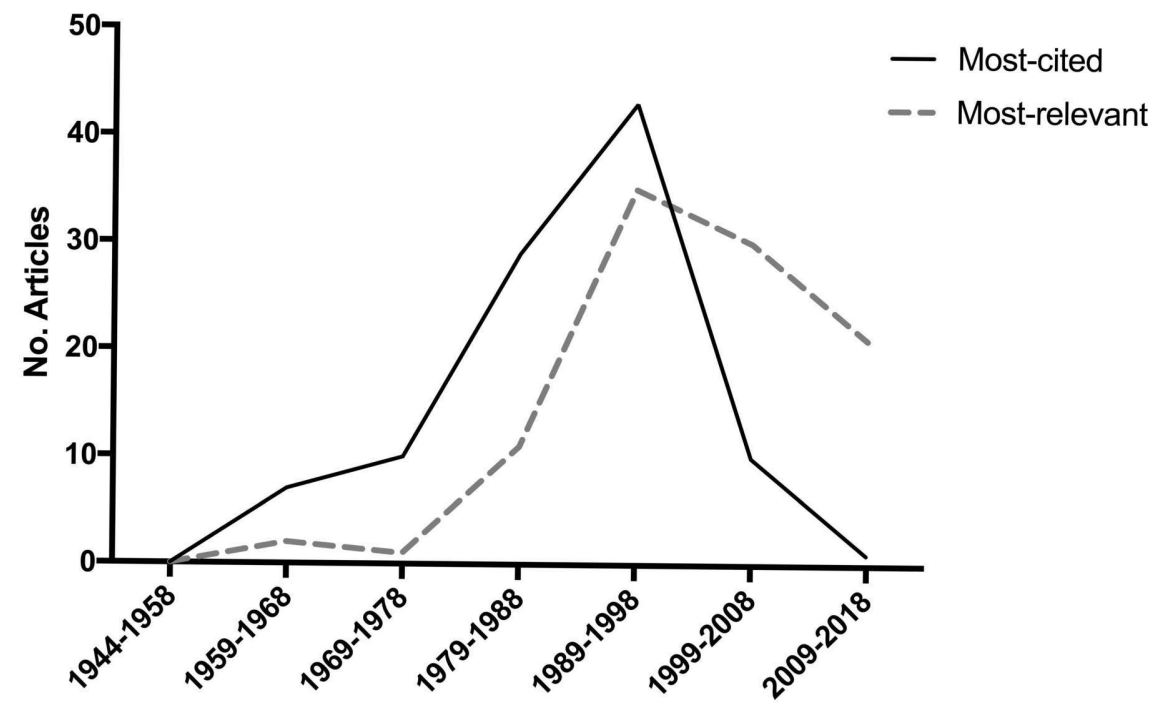

FIGURE 1: Trends in the 100 most cited vs. most relevant articles over time. 


\section{Cureus}

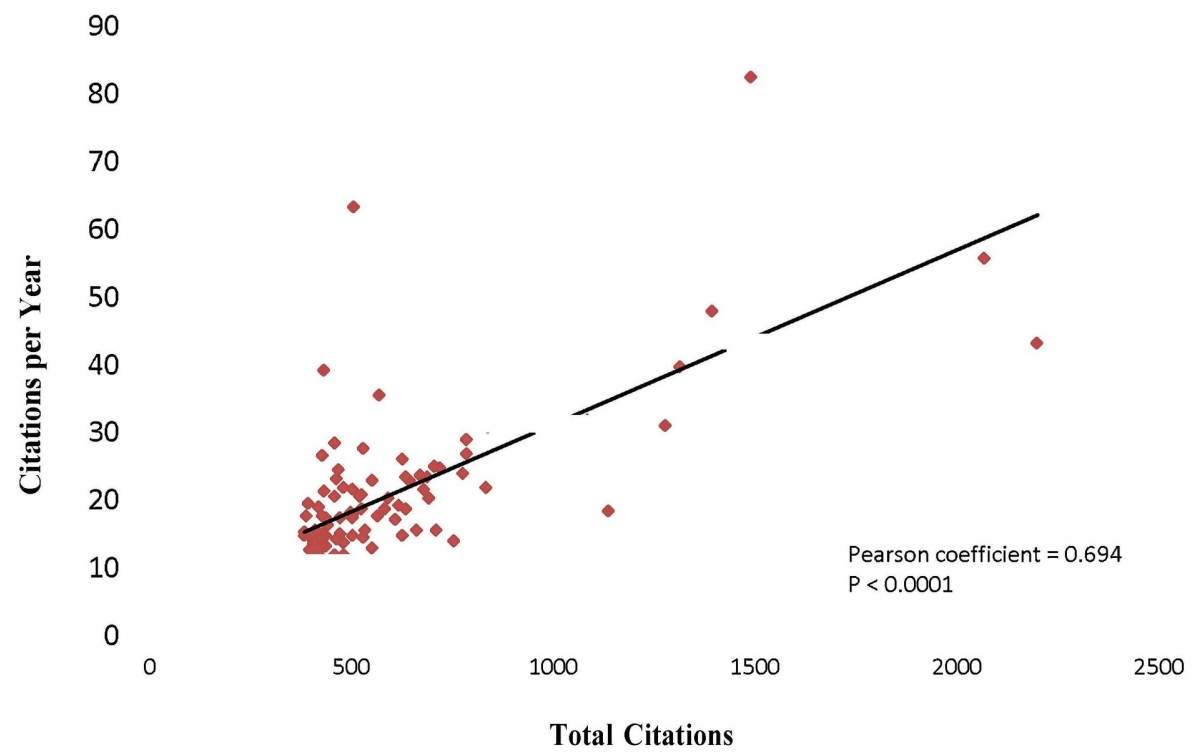

FIGURE 2: Positive correlation between the total number of citations and the number of citations per year.

Citations per Year

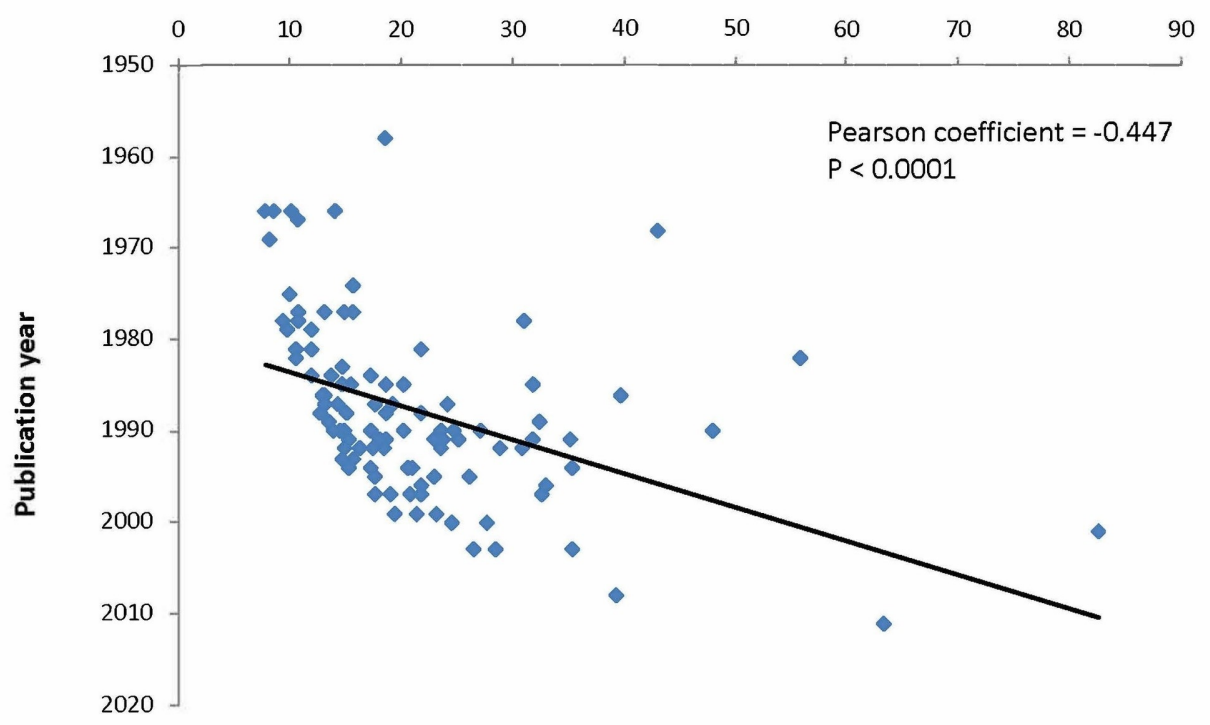

FIGURE 3: Negative correlation between the number of citations per year and the number of years since publication.

\section{Sources}

North American institutions contributed to the majority of the top cited 100 articles ( $\mathrm{n}=77)$, with Sweden following with five articles. The rest of the articles on the list originated from nine different countries including Switzerland, Italy, United Kingdom, Finland, Germany, Japan, France, Austria, and the former Soviet Union (Table 3). 


\section{Cureus}

\begin{tabular}{|c|c|c|c|c|c|c|c|c|c|}
\hline \multirow[t]{3}{*}{ Variable } & \multicolumn{8}{|c|}{ The 100 most cited articles } & The 100 most relevant \\
\hline & \multicolumn{8}{|c|}{ Citation count } & \multirow[b]{2}{*}{ Total } \\
\hline & Total & $>2000$ & $\begin{array}{l}1001- \\
2000\end{array}$ & $\begin{array}{l}801- \\
1000\end{array}$ & $\begin{array}{l}601- \\
800\end{array}$ & $\begin{array}{l}501- \\
600\end{array}$ & $\begin{array}{l}401- \\
500\end{array}$ & $\begin{array}{l}301- \\
400\end{array}$ & \\
\hline Total & 100 & 2 & 6 & 6 & 21 & 19 & 38 & 8 & 100 \\
\hline \multicolumn{10}{|l|}{ Country of origin } \\
\hline US & 72 & 1 & 6 & 3 & 13 & 16 & 27 & 6 & 71 \\
\hline Canada & 5 & l & I & 1 & 2 & I & 2 & l & 3 \\
\hline Sweden & 5 & l & I & 1 & 2 & 1 & 1 & l & 3 \\
\hline Switzerland & 3 & 1 & I & I & 1 & 1 & 1 & l & 2 \\
\hline Italy & 3 & l & I & 1 & 1 & I & 1 & l & 4 \\
\hline UK & 3 & l & I & I & I & I & 1 & 2 & 4 \\
\hline Finland & 2 & I & I & I & 1 & I & 1 & I & 2 \\
\hline Germany & 2 & l & I & I & I & 1 & 1 & I & 3 \\
\hline Japan & 2 & I & I & I & I & I & 2 & l & 1 \\
\hline France & 1 & I & I & I & 1 & I & I & I & 4 \\
\hline Others & 2 & 1 & 1 & 1 & 1 & 1 & 1 & 1 & 3 \\
\hline \multicolumn{10}{|l|}{ Topic of article } \\
\hline Cerebrovascular & 41 & 2 & 2 & 2 & 12 & 7 & 15 & 1 & 36 \\
\hline Trauma & 26 & l & 1 & 2 & 7 & 2 & 8 & 6 & 20 \\
\hline Tumor & 18 & 1 & 2 & 1 & 1 & 7 & 8 & 1 & 30 \\
\hline Functional neurosurgery & 11 & 1 & I & 2 & 1 & 2 & 6 & 1 & 12 \\
\hline Others & 4 & 1 & 1 & 1 & 1 & 1 & 1 & 1 & 2 \\
\hline \multicolumn{10}{|l|}{ Type of article } \\
\hline Clinıcal studies & 81 & 2 & 5 & 3 & 15 & 18 & 32 & 6 & 16 \\
\hline Laboratory studies & 12 & 1 & 1 & 2 & 4 & 1 & 4 & 2 & 10 \\
\hline Reviews/ meta-analysıs & $r$ & 1 & 1 & 1 & 2 & 1 & 2 & 1 & 14 \\
\hline $\begin{array}{l}\text { Guidelines/ consensus } \\
\text { statements }\end{array}$ & 1 & & & & & & & & 1 \\
\hline
\end{tabular}

TABLE 3: Summary of the 100 most cited articles based on citation count vs. summary of the 100 most relevant articles

The top institutions with corresponding author contributing three or more articles are shown in Figure 4. The Medical College of Virginia, of Virginia Commonwealth University, was the leading center on the top cited list, with 10 articles all addressing traumatic brain injury (TBI), followed by University of Pittsburgh Medical Center with seven articles. Lund University Hospital in Sweden and the University of Rome in Italy shared the most productive international institutions, with each contributing three articles. 


\section{Cureus}

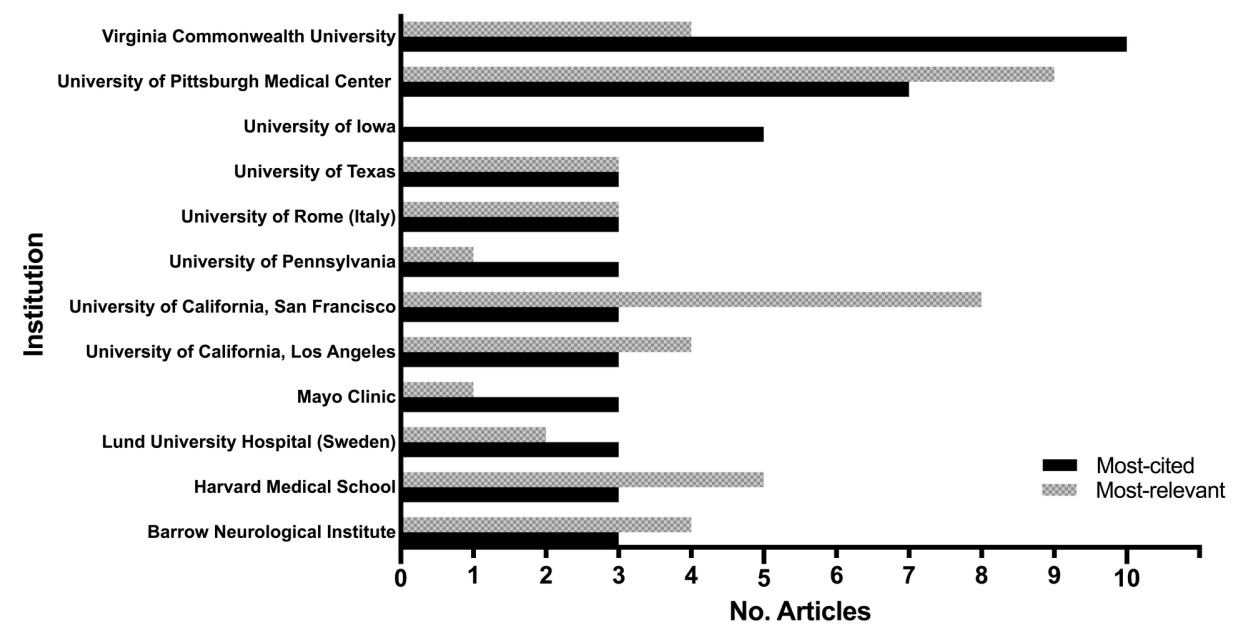

FIGURE 4: Institutions with corresponding author contributing three or more articles to the top 100 most cited and top 100 most relevant articles from the Journal of Neurosurgery.

Authors who contributed three or more articles to the top cited list are shown in Table 4 with their position on the author list. Anthony Marmarou and Harold F. Young shared the top of the most productive authors ranking contributing seven articles each. Anthony Marmarou and Guido Guglielmi contributed the highest number of research articles $(n=3)$ as the first author, while Bo K. Siesjo contributed three review articles as first and sole author. 


\section{Cureus}

\begin{tabular}{|c|c|c|c|}
\hline Name & No. of articles & Position on author list & Article Number* \\
\hline Marmarou, Anthony & 7 & First (3), Second (1), Sixth (1), Eighth (1), Senior† (1) & $12,17,27,71,91,98,100$ \\
\hline Young, Harold F & 7 & Fifth (2), Sixth (1), Seventh (1), Eighth (1), Ninth (1), Tenth (1) & $17,27,28,51,66,91,92$ \\
\hline Becker, Donald P & 6 & First (1), Second (2), Sixth (1), Ninth (1), Tenth (1) & $15,27,28,42,66,90$ \\
\hline Marshall, Lawrence F & 6 & First (1), Third (1), Fifth (1), Seventh (1), Ninth (1), Tenth (1) & $34,55,91,93,94,96$ \\
\hline Miller, J Douglas & 5 & First (2), Second (1), Third (1), Eighth (1) & $28,42,66,90,94$ \\
\hline Vinuela, Fernando & 5 & First (1), Second (3), Eighth (1) & $11,21,23,38,59$ \\
\hline Choi, Sung C & 5 & Third (1), Fourth (1), Fifth (3) & $27,51,66,90,92$ \\
\hline Torner, James C & 4 & Second (2), Third (1), Fourth (1) & $4,25,45,70$ \\
\hline Duckwiler, Gary & 4 & Second (1), Third (2), Fourth (1) & $11,21,38,59$ \\
\hline Jane, John A & 4 & Third (1), Fourth (1), Sixth (1), Seventh (1) & $4,25,91,94$ \\
\hline Guglielmi, Guido & 3 & First (3) & $11,23,59$ \\
\hline Siesjo, Bo K & 3 & First (3) & $16,31,84$ \\
\hline Jannetta, Peter J & 3 & First (2), Second (1) & $40,68,76$ \\
\hline Muizelaar, J Paul & 3 & First (1), Second (2) & $27,51,92$ \\
\hline Gennarelli, Thomas A & 3 & First (1), Second (1), Fifth (1) & $35,63,94$ \\
\hline Spetzler, Robert F & 3 & First (1), Third (1), Senior† (1) & $5,29,83$ \\
\hline Eisenberg, Howard M & 3 & First (1), Fourth (1), Sixth (1) & $34,55,91$ \\
\hline Ward, John D & 3 & Third (3) & $27,28,42$ \\
\hline Wilson, Charles B & 3 & Third (1), Fifth (1), Tenth (1) & $6,72,81$ \\
\hline Berger, Mitchel S & 3 & Fourth (1), Eleventh (1), Senior† (1) & 10, 50,79 \\
\hline
\end{tabular}

\section{TABLE 4: Authors contributing three or more articles to the 100 most cited articles}

${ }^{*}$ Refers to the article number in Table 1

† Rank last in the author list as corresponding author

\section{Topic of article}

Articles were classified into four categories including cerebrovascular, trauma, tumor, and functional neurosurgery. Ninety-six percent of articles fit into such classifications while four articles not classified by these categories were related to infection and cerebrospinal fluid system (numbers 8, 47, 71, and 98 in Table 1). A detailed breakdown of different study topics is shown in Table 5 .

\begin{tabular}{|l|l|l|}
\hline Topic of article & No. of articles & Article Number* \\
\hline Cerebrovascular & 41 \\
\hline IA and/or SAH & 16 & $11,21,22,23,38,59,95$ \\
\hline Endovascular treatment & 7 & $1,4,25,26$ \\
\hline Open surgery & 4 & $19,69,75,86$ \\
\hline Natural history & 4 & 89 \\
\hline Endoscopic surgery for spontaneous SAH & 1 &
\end{tabular}




\section{Cureus}

\begin{tabular}{|c|c|c|}
\hline Vascular malformations & 17 & \\
\hline Intracranial AVM & 9 & $5,20,45,48,52,60,64,70,73$ \\
\hline Cavernous malformation & 5 & $29,49,77,78,83$ \\
\hline CCSF & 1 & 30 \\
\hline SDAVF & 1 & 41 \\
\hline Miscellaneous & 1 & 43 \\
\hline Cerebral blood flow and ischemia & 8 & \\
\hline Pathophysiology & 4 & $14,16,31,84$ \\
\hline Treatment & 2 & 32,82 \\
\hline Transcranial Doppler study of blood flow & 2 & 2,57 \\
\hline Trauma & 26 & \\
\hline Mild TBI: pathophysiology, outcome & 2 & 15,34 \\
\hline Severe TBI & 13 & \\
\hline Monitoring of ICP and prognostic factors for outcome & 6 & $42,66,90,91,94,96$ \\
\hline Cerebral circulation & 3 & $35,51,92$ \\
\hline ICU management and surgery & 2 & 27,28 \\
\hline Therapeutic hypothermia & 2 & 88,99 \\
\hline $\mathrm{SCl}$ & 6 & \\
\hline Pathophysiology & 1 & 9 \\
\hline Anterior approach for ruptured cervical disks & 1 & 7 \\
\hline Atlantoaxial transarticular screw fixation & 1 & 97 \\
\hline Percutaneous vertebroplasty/kyphoplasty in cancer patients & 1 & 67 \\
\hline Methylprednisolone/naloxone treatment for acute SCI & 1 & 55 \\
\hline Motor function assessment in rat $\mathrm{SCl}$ model & 1 & 33 \\
\hline Other & 5 & \\
\hline Animal models & 3 & $12,17,100$ \\
\hline Prognostic factors for survival & 1 & 93 \\
\hline Shaken baby syndrome & 1 & 63 \\
\hline Tumor & 18 & \\
\hline Glioma & 7 & \\
\hline Extent of resection and prognostic factors for survival & 5 & $3,46,50,79,85$ \\
\hline Chemotherapy and/or radiation & 1 & 6 \\
\hline Image-based stereotaxic biopsy & 1 & 39 \\
\hline Sellar/parasellar tumors, transsphenoidal approaches & 3 & $36,56,62$ \\
\hline Meningioma: surgical outcome, postoperative irradiation & 2 & 24,72 \\
\hline Others & 6 & \\
\hline Germ cell tumors & 2 & 44,65 \\
\hline PCNSL & 1 & 37 \\
\hline
\end{tabular}




\section{Cureus}

$\begin{array}{lcc}\text { Atypical teratoid/rhabdoid tumor } & 1 & 54 \\ \text { Ependymoma } & 1 & 74 \\ \text { Medulloblastoma } & 1 & 81 \\ \text { Functional neurosurgery } & 11 & \\ \text { Disorders } & 3 & 13,18,53 \\ \text { Parkinson disease and other movement disorders } & 3 & 40,68,76\end{array}$

Procedures

DBS

Implantation of biological agents

Pallidotomy

MVD

Diagnostic studies

Cortical language localization by electric stimulation mapping

Somatic sensory and motor localization by cortical evoked potentials

\section{Stereotaxy}

Frameless stereotaxy with integration of CT and microscope

Conformity index for radiosurgery

Other

Neurologic manifestations of AIDS

4

Syringomyelia

Mathematical model of CSF system and ICP dynamics

1

1

2
8

47

71,98

\section{TABLE 5: The 100 most cited articles by topic}

AIDS = acquired immunodeficiency syndrome, $A V M=$ arteriovenous malformation, $C T=$ computed tomography, CCSF $=$ carotid-cavernous sinus fistula $\mathrm{DBS}=$ deep brain stimulation, IA = intracranial aneurysms, CSF = cerebrospinal fluid, ICP = intracranial pressure, ICU = intensive care unit, MRI = magnetic resonance imaging, $\mathrm{MVD}=$ Microvascular decompression, $\mathrm{PCNSL}=$ Primary central nervous system lymphoma, $\mathrm{SAH}=$ subarachnoid hemorrhage, $\mathrm{SCI}=$ spinal cord injury, SDAVF = spinal dural arteriovenous fistula, $\mathrm{TBI}=$ traumatic brain injury

The most common topic of study was cerebrovascular $(\mathrm{n}=41)$. The best-represented subtopic was intracranial arteriovenous malformation $(\mathrm{AVM})(\mathrm{n}=9)$, followed by endovascular treatment for intracranial aneurysms $(\mathrm{n}=7)$.

Trauma studies represented the second most common topic $(n=26)$, with the majority addressing traumatic brain injury (TBI), which included mild TBI $(n=2)$, severe TBI $(n=13)$, animal models $(n=3)$, prognostic factors for survival $(n=1)$, and shaken baby syndrome $(n=1)$. The remaining six articles were related to spinal injury.

There were eighteen articles reporting tumor topics, of which seven addressed glioma. Of note, articles featuring the extent of surgical resection and other prognostic factors for survival represented the mainstay $(\mathrm{n}=5)$. Other tumor topics included studies on sellar/parasellar tumors, meningioma, and other less common tumors. 


\section{Cureus}

articles $(n=11)$. Subtopics pertaining to functional neurosurgery included movement disorders $(n=3)$, microvascular decompression $(n=3)$, diagnostic studies with electrical stimulation $(n=3)$, and stereotaxy $(\mathrm{n}=2)$.

\section{Type of article and level of evidence}

Articles were further classified according to the type of study into four categories which included clinical studies (retrospective, prospective, randomized controlled trials, case series, and case reports), laboratory studies, reviews/meta-analysis, and guidelines/consensus statements (Table 3). None of the articles were guidelines/consensus statements. There were 81 clinical studies, among which more than half were retrospective studies and case series $(n=46)$ corresponding to level IV/4 (NHMRC/CEBM) evidence. There were twenty-six prospective studies and seven randomized controlled trials corresponding to level III/2 and II/1b (NHMRC/ CEBM) evidence, respectively. None of the articles were systematic review/meta-analysis, and thus there was no level I/1 (NHMRC/CEBM) evidence. Six literature review articles were level V/5 (NHMRC/CEBM) evidence. A detailed breakdown of different study types along with their level of evidence is shown in Table 6.

\begin{tabular}{|c|c|c|c|c|}
\hline \multicolumn{2}{|l|}{$\begin{array}{l}\text { Level of } \\
\text { evidence }\end{array}$} & \multirow[t]{2}{*}{ Type of article } & \multirow[t]{2}{*}{$\begin{array}{l}\text { No. of } \\
\text { articles }\end{array}$} & \multirow[t]{2}{*}{ Article Number* } \\
\hline NHMRC & CEBM & & & \\
\hline I & 1 & $\begin{array}{l}\text { Systematic review/Meta- } \\
\text { analysis }\end{array}$ & 0 & \\
\hline II & $1 \mathrm{~b}$ & $\begin{array}{l}\text { Randomized controlled } \\
\text { trial }\end{array}$ & 7 & $6,27,55,81,88,89,99$ \\
\hline \multirow[t]{4}{*}{ III } & 2 & Original prospective & & \\
\hline & & Clinical & 22 & $\begin{array}{l}4,18,20,21,25,26,32,34,46,49,51,53,59,66,77,79,90,91,92,93 \\
94,95\end{array}$ \\
\hline & & Experimental & 4 & $2,39,47,57$ \\
\hline & 3 & Case-control study & 2 & 24,75 \\
\hline \multirow[t]{2}{*}{ IV } & 4 & $\begin{array}{l}\text { Original retrospective } \\
\text { study }\end{array}$ & 21 & $1,3,5,19,28,29,38,42,43,44,45,48,50,60,65,72,78,85,86,96,97$ \\
\hline & & Case series & 25 & $\begin{array}{l}7,10,11,13,22,30,35,36,40,41,52,54,56,58,62,63,64,67,68,69 \\
70,73,74,83,87\end{array}$ \\
\hline \multirow[t]{2}{*}{ V } & 5 & Expert opinion & 1 & 76 \\
\hline & & Review & 6 & $8,9,16,31,37,84$ \\
\hline \multirow[t]{2}{*}{0} & 0 & Animal study & 10 & $12,14,15,17,23,33,71,82,98,100$ \\
\hline & & Technical note & 2 & 61,80 \\
\hline
\end{tabular}

TABLE 6: The 100 most cited articles by type and level of evidence

$\mathrm{CEBM}=$ Centre for Evidence-based Medicine, $\mathrm{NHMRC}=$ National Health and Medical Research Council

* Refers to the article number in Table 1

List Comparisons

The list of 100 most relevant articles shows several differences compared with the list of 100 most cited articles. A significant number $(\mathrm{n}=41)$ of articles on the most relevant list are not included in the most cited list. Of the 59 articles remaining on both lists, 41 are among the top 50 on the most cited list.

The most relevant list, not surprisingly, contains considerably more recently published articles than the most cited list. As shown in Figure 1, there is a lag of almost a decade before the steep increase in the number of 


\section{Cureus}

the most relevant articles compared to that of the most cited articles. Though both plots peak in the 1990s, the one representing the most relevant list has a steadier decrease thereafter. The median year of publication is 1999 for the 100 most relevant articles, compared to 1990 for the 100 most cited articles $(\mathrm{P}<$ 0.0001). In addition, the most relevant list shows a more equitable pattern of article topic distribution than the most cited list (Table 3). While the most represented topic remains cerebrovascular $(n=36)$, there is a significant increase in the number of articles reporting tumor studies (30 vs. 18). Compared with the most cited list wherein five out of seven papers addressing glioma were related to malignant glioma, the most relevant list contains more studies on low-grade glioma, specifically with three articles addressing awake surgery with cortical and subcortical electrical mapping originating from the same team in France (numbers 34, 68, and 74 in Table 2). Additionally, there are two articles concerning radiosurgery for vestibular schwannoma and melanoma brain metastases, respectively (numbers 49 and 88 in Table 2). Though the most relevant list has a similar number of articles on functional neurosurgery compared with the most cited list (12 vs. 11), it has a broader coverage of disorders (e.g. epilepsy) and procedures (e.g. vagus nerve stimulation). There are fewer trauma articles in the most relevant list (20 vs. 26).

With regard to the type of article and the associated level of evidence, the most relevant list consists of twice as many review articles as the most cited list (14 vs. 7) (Table 3). Of note, six articles are systematic reviews/meta-analyses which correspond to level I/1 (NHMRC/CEBM) evidence. The number of prospective studies $(n=32)$ increased in the most relevant list while the number of retrospective studies $(n=37)$ decreased, corresponding to level III/2 and level IV/4 (NHMRC/ CEBM) evidence, respectively. The most relevant list has a similar number of randomized controlled trials $(n=6)$ and literature reviews $(n=8)$ compared with the most cited list which corresponds to level II/1b and V/5 (NHMRC/CEBM) evidence, respectively.

There seems to be no dramatic discrepancy regarding the country of origin of articles between the two lists (Table 3). With regard to institutional contributions, University of Pittsburgh Medical Center led the list with nine articles covering all four major topics, followed by the University of California at San Francisco with eight articles (Figure 4). Authors who contributed three or more articles to the most relevant list are shown in Table 7 with their position on the author list.

\begin{tabular}{|c|c|c|c|}
\hline Name & No. of articles & Position on author list & Article Number* \\
\hline Berger, Mitchel S & 6 & Fourth (1), Seventh (2), Eleventh (1), Senior† (2) & $2,17,28,41,57,97$ \\
\hline Vinuela, Fernando & 5 & First (1), Second (3), Eighth (1) & $8,16,18,31,94$ \\
\hline Duckwiler, Gary & 4 & Second (1), Third (2), Fourth (1) & $8,16,18,94$ \\
\hline Guglielmi, Guido & 3 & First (3) & $18,31,94$ \\
\hline Marmarou, Anthony & 3 & First (1), Second (1), Sixth (1) & $9,36,38$ \\
\hline Becker, Donald P & 3 & Second (1), Sixth (1), Eleventh (1) & $27,38,99$ \\
\hline Young, Harold F & 3 & Fifth (1), Seventh (1), Eighth (1) & $36,38,86$ \\
\hline
\end{tabular}

\section{TABLE 7: Authors contributing three or more articles to the 100 most relevant articles}

* Refers to the article number in Table 2

† Rank last in the author list as corresponding author

\section{Discussion}

As the official journal of AANS and one of the top journals in the field of neurosurgery, JNS has published over 21,933 articles since 1944 . Its significant academic influence and considerable contribution to the evolution of modern neurosurgery has been recognized not only by the steadily increasing JCR impact factor scores, but also by previous citation analyses on the top cited and most relevant works in neurosurgery. These analyses identified JNS as the number one neurosurgical journal on both lists, contributing 79 articles to the 100 top cited list and 63 articles to the 100-most relevant list among all neurosurgical journals [35]. However, analysis remains elusive regarding the articles, authors, institutions, and topics that are driving the achievement and progress of JNS.

This bibliometric analysis identified the 100 most cited and most relevant articles published in JNS since its 
first issue launched in 1944. The two lists represented here may serve as the most objective and reliable resources in defining the classic and foundational works of the journal as well as the field of neurosurgery to some extent, because this modality is less influenced by subjective bias [14]. Indeed, a set of seminal articles which have had significant influence over both practice and research in the field of neurosurgery were included in the lists. These may also serve as fundamental reading lists for the education of neurosurgical residents.

Both the 100 most cited and most relevant lists displayed a so-called "90s peak" regarding the temporal trends in published articles, which has been reported in previous citation analyses as well [4, 15]. This phenomenon may be explained by several factors including (1) the transition point where older works are losing their relevance in modern practice to newer works just beginning to accumulate citations; (2) a dramatic increase in citation indexing boosted by online databases which emerged around 2005 [4]; and (3) an expanding number of neurosurgeons and researchers in the field which may result in increased citations of more recently published articles. In addition, there seems to be a predictable course for articles to accumulate citations around two years after publication, peak after three to ten years, and then decline over time $[4,16]$. It would then be expected that articles published in the most recent decade will accumulate citations and peak in the following years. The strategy to identify the 100 most relevant articles by ranking the literature according to citations per year has to some extent overcome the inherent problem of citation analyses which favors older publications by using total citations as a measure of impact [5, 17].

It is not surprising that institutions from North America contributed to the majority of articles on both lists. The disparity in numbers between the US and other countries may be attributed to several reasons including (1) the inherent association of AANS with JNS as official journal; (2) the fact that government funding and resources allocation for research was several times higher in the US than other countries [1819]; (3) the possible bias associated with our classification strategy according to the corresponding author's institution as many studies enjoy multi-center cooperation; and (4) the inherent bias of the JNS being an English-language publication and the US as a primarily English-speaking nation (at least in matters of scientific discovery). However, international institutions located in 131 countries from other continents have made considerable contributions as well, which further validate the academic influence of JNS worldwide. This analysis also highlighted the significant contribution of many neurosurgeons to the growth and achievements of JNS. The contributors listed herein should not only be considered as a memorial for young generations to admire, but also as an impetus to inspire.

This bibliometric analysis also revealed the characteristics and trends of research in neurosurgery, which may also shed light on the direction for future research. The 100 most cited and most relevant lists both showed a strong focus on cerebrovascular disorders and procedures, with the latter group featuring more large-scale and well-designed studies on new techniques or first-hand experiences with new devices, such as Onyx injection for intracranial AVM, flow diverters, stents, indocyanine green videoangiography for aneurysm surgeries, and neurotransplantation for stroke patients. Similarly, distinguishing characteristics of the two lists concerning the topic of tumor are revealed by the significant increase in the number of articles related to the newly developed technique of awake surgery with functional electrical mapping for patients with low-grade glioma, the advancement of endoscopic endonasal approaches, surgical techniques for resection of a wider range of skull base tumors, and the application of radiosurgery for treatment of a variety of benign and malignant brain tumors.

With regard to functional neurosurgery, which represents one of the fastest-developing subspecialties, articles on management of refractory mood disorders and seizure disorders with stimulators emerged in the most relevant list compared with the most cited list, while trauma studies, which are thought to lose some of their popularity to more current hot topic research areas, did decrease in total numbers from 26 in the most cited list to 20 in the most relevant list. Of note, there were more articles on mild TBI and laboratory research on pathophysiology as well as cutting-edge diagnostic and therapeutic (in animal models) modalities in the latter group.

Though the majority of articles were original clinical studies, there were seven and 14 review articles among the 100 most cited and most relevant articles, respectively. Six systematic reviews/meta-analyses, which were exclusively included in the most relevant list, corresponded to level I evidence and could influence clinical practice and research directions as they are able to pool data from individual under-powered studies with disagreeing results and draw conclusions using statistical tools. Alternatively, the importance of literature review articles was noted in both lists as they offer a current overview of the field with synthesis of related individual studies and/or expert opinions on a specific topic [4].

The majority of articles in the 100 most cited list corresponded to level III (original prospective studies, $\mathrm{n}=28$ ) and level IV (retrospective studies, $\mathrm{n}=46$ ) evidence. Of note, there was no systemic review/metaanalysis representing level I evidence, and there was only one article in the top 20 with high-level evidence (I or II) as a randomized controlled trial, which seemed fewer in number than previous citation analyses on other subspecialty journals [6, 20-21]. However, the overall number of articles with high-level evidence 
increased significantly in the most relevant list, with six systemic reviews/meta-analyses and six randomized controlled trials, which was higher than other subspecialized analyses [6,22] and reflected the trend of increasing high-quality studies valued by the scientific community.

With the fact of more recently published articles and more level I evidence included in the most relevant vs. the most cited list, it is important to acknowledge unique characteristics and the usefulness of each list. The most cited list provides a better blueprint of the foundation and development of the field from a more historical perspective, while the most relevant list points to the science underlying current practice and future directions [3]. Either of the two lists can be used under different circumstances. With the push for evidence-based medicine that started in the 1990s, lists such as these will be very important in substantiating current practice methods, modification of practice, surgical techniques, and quality of care. If viewed from within this framework of evidence-based practice, bibliometric studies such as this one will become the tools that demonstrate neurosurgery's commitment to evidence-based practice to the world. It can also be easily inferred that with data provided from bibliometrics analysis such as these, the medical establishment can also exert the necessary influence in things such as insurance coverage of treatments deemed "experimental", reimbursements, and encourage a decrease in unnecessary procedures.

There are several limitations to this bibliometric analysis. First, some important recent publications with high numbers of citations per year but relatively low total citations may have escaped detection by our search strategy. Alternatively, the relevance of these articles may need to be tested by time according to the pattern of accumulating citations. Furthermore, with the evolution of a single JNS into the JNS publishing group, the official journals of AANS now include an additional three independent journals. This includes (1) Journal of Neurosurgery: Spine (since 2004) focusing on spinal surgery; (2) Journal of Neurosurgery: Pediatrics (since 2008) focusing on neurological diseases and disorders in children, and (3) Neurosurgical Focus (since 1996) covering a specific neurosurgical topic in depth for each issue. The current analysis limited its search to JNS only, and thus may have missed articles related to spine surgery, pediatric neurosurgery, and reviews published in the other three series. Additionally, certain landmark works may not have been captured if they have appeared in a textbook or published in a language other than English. Last but not least, as a "snapshot" analysis of published literature and their academic impact, any list created by citation analysis is dynamic and may change due to the function of time.

\section{Conclusions}

This bibliometric analysis identified the 100 most cited articles originating in JNS by total citation counts and the 100 most relevant articles in JNS by citations per year. The findings revealed the key contributing factors to the growth and flourish of JNS as well as classic and foundational works in the field of modern neurosurgery. Discrepancies between the most-cited and most-relevant lists also suggested that studies incorporating newly developed modalities, high-quality clinical trials and laboratory investigations, and systematic reviews with level I evidence are of growing interest and will likely be areas of continued growth in the future. Bibliometric analysis serves as a useful tool to establish benchmarks in the development of the field and to propose career directions in future research and practice.

\section{Additional Information \\ Disclosures}

Human subjects: All authors have confirmed that this study did not involve human participants or tissue. Animal subjects: All authors have confirmed that this study did not involve animal subjects or tissue. Conflicts of interest: In compliance with the ICMJE uniform disclosure form, all authors declare the following: Payment/services info: All authors have declared that no financial support was received from any organization for the submitted work. Financial relationships: All authors have declared that they have no financial relationships at present or within the previous three years with any organizations that might have an interest in the submitted work. Other relationships: All authors have declared that there are no other relationships or activities that could appear to have influenced the submitted work.

\section{References}

1. Journal of Neurosurgery overview . (2019). Accessed: April 17, 2019: https://thejns.org/view/journals/jneurosurg/j-neurosurg-overview.xml.

2. Latest impact factors journal list, Thomson Reuters based on 2017 journal citation reports . (2018). Accessed: February 2019: https://www.researchgate.net/publication/326096765_2018Latest_Impact_Factors_Journal_ListThomson_Reuters_base

3. Bohl MA, Ponce FA: Assessing the relevancy of highly cited works in neurosurgery. Part I: the 100 most relevant papers in neurosurgical journals. World Neurosurg. 2017, 104:927-938. 10.1016/j.wneu.2017.03.149

4. Hachem LD, Mansouri A, Juraschka K, Taslimi S, Pirouzmand F, Zadeh G: Citation classics in neurooncology: assessment of historical trends and scientific progress. Neuro Oncol. 2017, 19:1158-1172. 10.1093/neuonc/nox053.

5. Ponce FA, Lozano AM: Highly cited works in neurosurgery. Part I: the 100 top-cited papers in neurosurgical 
journals. J Neurosurg. 2010, 112:223-232. 10.3171/2009.12.JNS091599.

6. Ren Y, Kok HK, Zhou K, et al.: The 100 most cited articles in the Journal of NeuroInterventional Surgery . J Neurointerv Surg. 2018, 10:1020-1028. 10.1136/neurintsurg-2018-014079

7. Yadava SM, Patrick HS, Ananth CV, Rosen T, Brandt JS: Top-cited articles in the Journal: a bibliometric analysis. Am J Obstet Gynecol. 2019, 220:12-25. 10.1016/j.ajog.2018.11.1091

8. Zeleznik D, Blazun Vosner H, Kokol P: A bibliometric analysis of the Journal of Advanced Nursing, 19762015. J Adv Nurs. 2017, 73:2407-2419. 10.1111/jan.13296

9. Efron N, Brennan NA, Nichols JJ: Citation analysis of the contact lens field . Optom Vis Sci. 2012, 89:70-9. 10.1097/OPX.0b013e318236dcca

10. Merlin T, Weston A, Tooher R: Extending an evidence hierarchy to include topics other than treatment: revising the Australian 'levels of evidence'. BMC Med Res Methodol. 2009, 9:34. Accessed: April 17, 2019: 10.1186/1471-2288-9-34

11. Oxford Centre for Evidence-based Medicine - levels of evidence . (2019). Accessed: April 17, 2019: https://www.cebm.net/category/ebm-resources/loe/.

12. Hunt WE, Hess RM: Surgical risk as related to time of intervention in the repair of intracranial aneurysms . J Neurosurg. 1968, 28:14-20. 10.3171/jns.1968.28.1.0014

13. Lacroix M, Abi-Said D, Fourney DR, et. al.: A multivariate analysis of 416 patients with glioblastoma multiforme: prognosis, extent of resection, and survival. J Neurosurg. 2001, 95:190-198. 10.3171/jns.2001.95.2.0190

14. Flores LY, Rooney SC, Heppner PP, Browne LD, Wei MF: Trend analyses of major contributions in the Counseling Psychologist cited from 1986 to 1996: impact and implications. Couns Psychol. 1999, 27:73-95.

15. Lipsman N, Lozano AM: Measuring impact in stereotactic and functional neurosurgery: an analysis of the top 100 most highly cited works and the citation classics in the field. Stereotact Funct Neurosurg. 2012, 90:201-209. 10.1159/000337170

16. Uthman OA, Okwundu CI, Wiysonge CS, Young T, Clarke A: Citation classics in systematic reviews and meta-analyses: who wrote the top 100 most cited articles?. PLoS One. 2013, 8:78517. Accessed: April 17, 2019: 10.1371/journal.pone.0078517

17. Gisvold SE: Citation analysis and journal impact factors--is the tail wagging the dog? . Acta Anaesthesiol Scand. 1999, 43:971-973. 10.1034/j.1399-6576.1999.431001.x

18. Sobocki P, Lekander I, Berwick S, Olesen J, Jonsson B: Resource allocation to brain research in Europe (RABRE). Eur J Neurosci. 2006, 24:2691-2693. 10.1111/j.1460-9568.2006.05116.x

19. Pope WB, Itagaki MW: Characterizing brain tumor research: the role of the National Institutes of Health . AJNR Am J Neuroradiol. 2010, 31:605-609. 10.3174/ajnr.A1904

20. Elgafy HK, Miller JD, Hashmi S, Ericksen S: Top 20 cited Spine Journal articles, 1990-2009. World J Orthop. 2014, 5:392-397. 10.5312/wjo.v5.i3.392

21. Lefaivre KA, Guy P, O'Brien PJ, Blachut PA, Shadgan B, Broekhuyse HM: Leading 20 at 20: top cited articles and authors in the Journal of Orthopaedic Trauma, 1987-2007. J Orthop Trauma. 2010, 24:53-58. 10.1097/BOT.0b013e3181aa2182

22. Khan NR, Auschwitz T, McAbee JH, Boop FA, Klimo P Jr: Highly cited publications in pediatric neurosurgery: part 2. Childs Nerv Syst. 2013, 29:2215-2228. 10.1007/s00381-013-2293-3 